\title{
Charlotte Libraries Tackle Controversial Topic
}

EDITORIAL

Beth Scarborough and Susan Foster Pardue

University of North Carolina, Charlotte
Beyond the Myths

$\mathrm{F}$ Iive years after white supremacist Dylann Roof shot and killed nine members of a Bible study class at Emanuel African Methodist Episcopal Church in Charleston, South Carolina, Minneapolis police officers suffocated George Floyd on a city street, causing his death. The viral video of that act of violence was the breaking point: years of oppression, violence, and racial injustice culminated in protests for rights of Black Americans throughout the United States. One by one, Confederate monuments began tumbling from their pedestals throughout the South. For over a hundred years the monuments have stood for white supremacy and oppression, flagrant signs to Black Americans that they do not have a place in society, signs intentionally planted by the United Daughters of the Confederacy in the early twentieth century. Today those outward signs of oppression are finally crumbling. People are tired of racial violence. What can stop it? What can help people understand that Black Lives Matter does not mean only Black lives? How can generations of White Southerners, raised to ignore systemic racism and to believe in myths disseminated through popular films such as Birth of a Nation and Gone with the Wind, understand the truths of history and their own privilege? Can libraries help change opinion and reveal the truth? Is that a library's responsibility?

Companies, organizations, and governments throughout the country are publishing diversity and inclusion statements, pledging support to Black Lives Matter, and expressing abhorrence of discrimination of all kinds. Many agencies and organizations, including libraries, have long been agents for social justice and change. Though libraries have often tried to be politically neutral and unbiased stewards of information, they cannot-especially today. Libraries have to take a stand. Jane Cowell said that as part of critical librarianship, libraries should promote truth and root out false information, thereby providing a platform for conversations that will strengthen communities and democracy (Cowell 2020, 30). In discussing critical librarianship, Emily Drabinski said, "At the heart of critical librarianship, for me, is a conviction and a radical hope that things could be different from the way they are now." (Drabinski 2019,53)

In Charlotte, North Carolina, librarians took on the elephant in the room. University of North Carolina (UNC) Charlotte and Charlotte Mecklenburg libraries took a lead role in shining a light on racial injustices and deep histories hidden behind the Confederacy. By examining North Carolina's role in the Confederacy and the leading part the United Daughters of the Confederacy played in maintaining white supremacy and racism throughout the South, the libraries sought truths at a time of racial upheaval. 
The impetus for the project was sparked, in part, when the UNC Chapel Hill Confederate statue, Silent Sam, became the center of attention in the state. Erected in 1913, Silent Sam had long been a subject of controversy. Confederate monuments, primarily erected by the United Daughters of the Confederacy in the early twentieth century, served to memorialize Confederate veterans and mythologize Old South culture as a means of venerating slavery. In North Carolina, the contentious debate over memorials led to the enactment of Session Law 2015-170, Senate Bill 22 protecting public memorials, plaques, statues, or markers considered "objects of remembrance." Though most students and faculty wanted Silent Sam removed, campus officials at UNC Chapel Hill claimed the new law prevented the removal of the statue from the campus entrance.

Then, in August 2017, white supremacists descended on Charlottesville, Virginia, protesting the removal of a statue of Robert E. Lee. Amid violence between protesters and counter-protesters, James Fields, a confirmed neoNazi, crashed his car into a group of counter-protesters, killing Heather Heyer and wounding thirty-five, many very seriously (Duggan 2018). Protests over Silent Sam then ramped up at the UNC Chapel Hill campus. University board members and North Carolina legislators wanted the statue to stay; Chancellor Carol Folt said her hands were tied by the legislation (Patel 2018). While officials dragged their feet, the issue became more intense with fierce debate from both sides until protesters finally toppled Silent Sam from his nine-foot pedestal in August 2018.

\section{The Programs}

As tensions mounted in Chapel Hill, Atkins Library faculty and staff talked about how to address the issues simmering beneath the surface. No one in Charlotte appeared to be having a public conversation about it; was this something a library could take a stand on? Many thought it a good idea, but the library had no funds to bring outside authorities to campus, and the UNC Charlotte Department of History faculty experts on the Confederacy were on sabbatical or book tours. We submitted a grant proposal to the North Carolina LSTA (Library Services and Technology Act) fund, but it was rejected. Still, the topic loomed as an important one; no one at Atkins Library was ready to give up so easily.

Dean Anne Cooper-Moore kept the topic fresh on the minds of library staff and thought it a good project for the library's newly formed board of advisors to get behind. The board liked the idea, too, but the problem with funding remained. Then a historian and grant writer on the board used her expertise to make contacts with a prominent faculty member in the history department, convincing her to become involved. The team, along with the Charlotte Mecklenburg Public Library, sought grant approval through the UNC Charlotte Chancellor's Diversity Challenge Fund for a series of public programs to be held in Charlotte. Its mission was to dispel myths about the Confederacy and to show how those myths evolved. It was the group's vision to illustrate that an accurate awareness of the past is essential to understanding present conflicts.

The series, entitled Beyond the Myths: The American Civil War in History and Memory, sought to explain the history and myths of North Carolina's role in the Civil War and those surrounding the presence of Confederate monuments in the United States, particularly the South.

The Chancellor's Diversity Challenge Fund approved the proposal in June 2018. Beyond the Myths kicked off on February 21, 2019, with the first of two major events. The final, large event closed the series on March 13, 2019. Three smaller, related programs were sandwiched in between the two larger ones. 
Beyond the Myths opened in the J. Murrey Atkins Library Halton Room with noted North Carolina history scholar Paul Escott discussing "North Carolina in History and Memory." Dr. Escott detailed how North Carolina, the last state to join the Confederacy, came to terms with impressment, conscription, and the Confederacy's highly centralized government: with protests, food riots, and high rates of desertion, particularly in the western and poorer counties. Nonslaveholders saw the war as a "rich man's war and a poor man's fight." (Escott and Crow 1986, 377-402)

Two smaller programs, genealogical workshops, emphasized a Black American and a North Carolina genealogy focus. Marcellaus Joiner, a North Carolina librarian and archivist, led the Black American genealogy workshop at the Sugar Creek branch of Charlotte Mecklenburg Library. Participants learned how unusual resources such as bastardy bonds and apprenticeship records may lead to ancestors not commonly found in United States census records. A North Carolina genealogy workshop offered by genealogical librarian Donna Gunter included the story Gunter discovered in her own search to find her Shelton family ancestors: In January 1863, a group of residents-including several members of the Shelton family of western North Carolina's Madison Countyraided a supply of salt that was being hoarded by Confederates. In retaliation, Confederates hunted and gunned down, without trial, thirteen members of the Shelton family in what became known as the Shelton Family Massacre (Bynum 1987, 45).

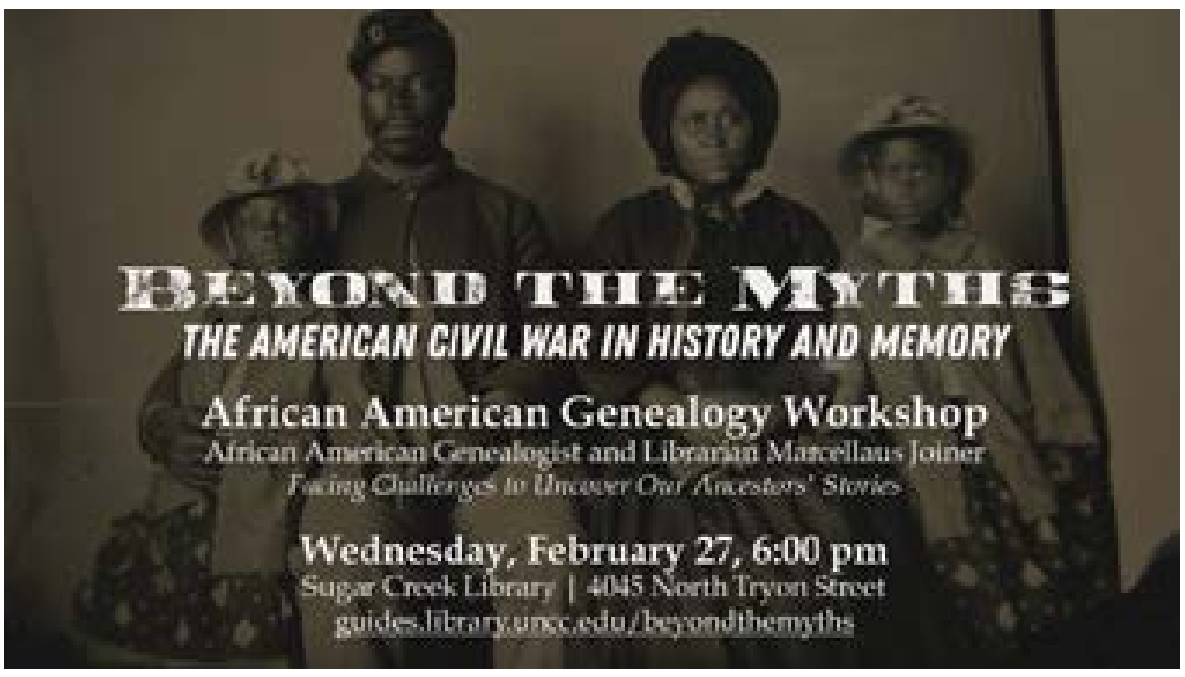

Figure 1: Atkins Library's marketing slide for genealogy workshop. (Photo unattributed, from Library of Congress Prints and Photographs Division.)

The addition of the genealogy programs allowed individuals to look at history through a personal lens. With the knowledge to understand themselves and their heritage, they increase their ability to understand others.

A film screening of the 2016 movie A Free State of Jones took place at the Sugar Creek Library. The movie examines the life of Newt Knight, a Mississippi farmer and Confederate soldier. Knight, disgusted by the sacrifices of young men for a cause he believed only benefitted the rich, deserted his position and started a rebellion against the Confederacy. Charlotte Mecklenburg Library historian Thomas Cole provided a historical commentary on the film and answered audience questions.

A panel presentation, "Commemorating the Confederacy: History, Memory and Meaning in the 21st Century South," completed the series. Dr. Karen Cox, UNC Charlotte professor of history and an authority on the United Daughters of the Confederacy, led the presentation. Joining Dr. Cox were Dr. William 
Sturkey of UNC Chapel Hill and Dr. Hilary Green of the University of Alabama. Dr. Sturkey specializes in the history of race in the American South. Dr. Green is in the Department of Gender and Race Studies and is program codirector of the African American Studies program.

The panel presented to an audience of more than 130 at the UNC Charlotte Center City campus, bringing to light the history and myths perpetuated by the United Daughters of the Confederacy. The panelists emphasized how the presence of Confederate monuments, particularly in public spaces, are an affront to Black Americans because the monuments represent and honor a time when Black Americans were enslaved. Whenever a Black American enters a state house or university where Confederate monuments are displayed, it signals to them that they do not belong. Guests peppered the panelists with questions at the conclusion of the presentation. This event was recorded.

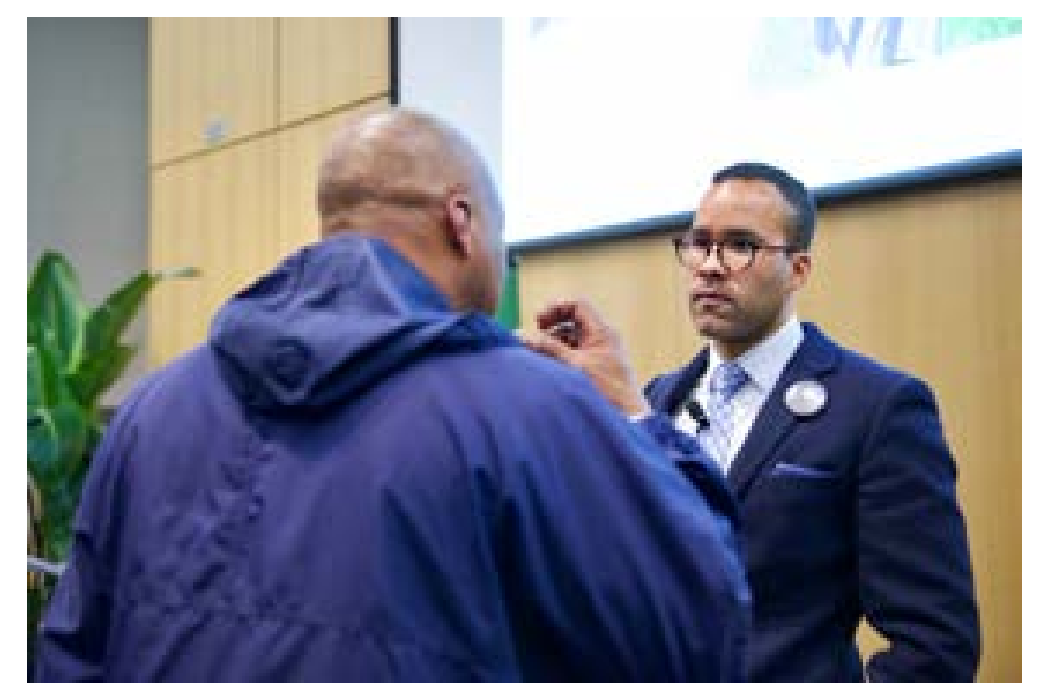

Figure 2: Dr. William Sturkey answers questions at the "Commemorating the Confederacy: History, Memory and Meaning in the Twenty-First Century South" presentation. (Photo by Lynn Roberson, UNC Charlotte.)

\section{The Planning}

The majority of the funds received from the Chancellor's Diversity Challenge Fund were used for speakers' fees. Dean Moore allocated discretionary funds to provide receptions at the larger events; this allowed speakers to mingle with the audience and answer specific questions. The Charlotte Mecklenburg Library purchased film screening rights and provided refreshments at each of the events held at Sugar Creek Library.

Considerable preparation went into the planning and marketing of the events. From the beginning it was clear this was not a one-evening program. To be heard, it had to be a series and it had to reach a varied audience-students and the public. Marketing was key to success. The library formed a committee to assist with planning and implementing the programs. Librarians created a detailed online research guide that not only highlighted each event but also provided resources for lesson plans and classroom assignments. A "special collections" tab on the guide provided links to digital sources and information on in-house sources. Links to books, e-books, and videos highlighted sources available to UNC Charlotte students and to the public.

E-mail proved to be the most effective form of marketing and communication. All UNC Charlotte faculty members received emails 
introducing the series as well as email reminders before each event. Several history faculty members supported the series by offering extra credit to students for their attendance. The library marketing team created graphic slides for each event and distributed those across campus, including displaying the slides on information monitors in the library and on the website. The library committee built an email list of history and political science faculty from colleges in Charlotte and the surrounding area. This list proved to be a successful marketing tool as several faculty and students from other colleges attended events. A group from one college located about fifty miles north of the UNC Charlotte Center City campus even arranged a vanpool to the panel presentation on Confederate memorials. A registration link on all marketing materials corresponded to an Eventbrite webpage for enrollment in each of the two major events. Eventbrite proved to be an effective tool for managing emails, reminders, questions, and follow-up.

The partnership with Charlotte Mecklenburg Library allowed us to tap into the marketing expertise of a large organization, dramatically increasing the outreach possibilities and reaching a varied audience. This also drew more visitors to Atkins Library, allowing patrons to peruse a very different collection from that of the public library. Atkins' Special Collections department played a large role in each event, staffing a display table with copies of historic

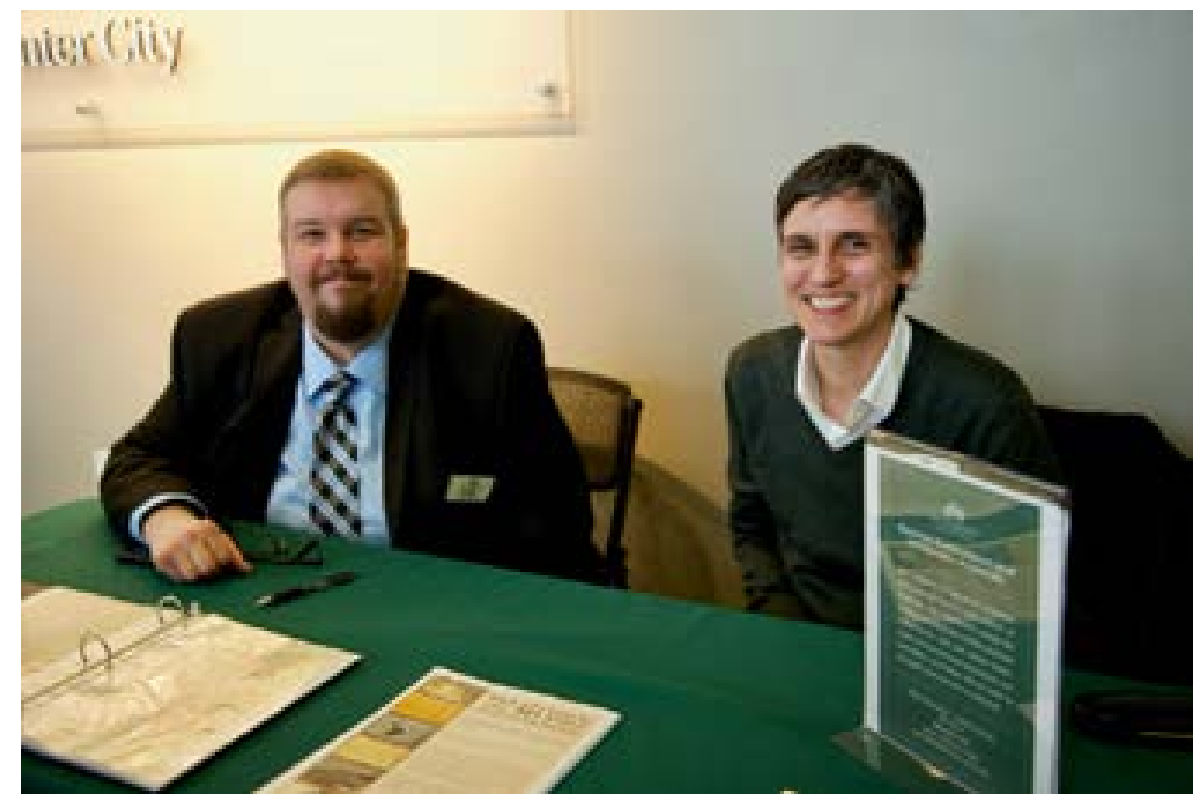

Figure 3: Special Collections faculty showcase Atkins Library archives at Beyond the Myths: The Civil War in History and Memory event. (Photo by Lynn Roberson, UNC Charlotte.)

documents and manuscripts housed in the collection, while also answering questions and showcasing archives.

The UNC Charlotte Communications department landed an appearance on local public radio station WFAE for Drs. Cox, Sturkey, and Green prior to the final panel presentation. "Charlotte Talks" personality Mike Collins interviewed the scholars, asking detailed questions about the topic while also promoting the final presentation. Many guests registered for the panel presentation as a result of the radio program, which was also archived on the radio station's website.

At the close of each program, detailed evaluation surveys were distributed to all guests either by email or in person; this gave the library the opportunity to gauge the success of the programs. The surveys encouraged guests to make recommendations on how to improve the presentations and to offer suggestions 
for future planning and programming. Many guests requested more historical programs; others desired topics of current interest, especially related to Charlotte and Mecklenburg County history. One attendee commented, "I liked the fact that this event reinvestigated something well-known in history to shed light on a new perspective. More events like this would be great."

The intent of the series was to provide truthful information; this did not include giving voice to those opposed to the removal of Confederate monuments or who promote the states' rights view of the Confederacy. (The claim that the South seceded over states' rights has long been proven a false claim. Dr. Escott's talk brought up the fact that the Confederate government was very centralized-quite the opposite of the states' rights claims-and asserted the war was very much about slavery.) The series demonstrated how memory is different from history: history is factual; memory is how the United Daughters of the Confederacy sought to create and perpetuate a false history-a history that posits slaves were treated like family, and that all soldiers volunteered and fought bravely for a cause they believed in. The series showed how the Lost Cause myth - one that has persisted for more than a hundred years-is dangerous. Those were the facts the library strove to reveal. That is what critical librarianship is all about.

The library and the university place a large focus on outreach to the public as well as to students. Librarians consistently plan exhibits and programs. Other historical programs have taken place at Atkins Library since the Beyond the Myths series. Several of the library's current committees focus on diversity, outreach, exhibits, and marketing. The committees open their membership to all library employees to take advantage of new and fresh ideas.

\section{Lessons Learned}

Always expect the unexpected. The University's Center City campus technology team planned to stream the final presentation via Facebook Live. However, on the day of the event, March 13, 2019, Facebook Live experienced one of the largest outages in its history when it went down across the Eastern United States. WhatsApp, Messenger, and Instagram were also affected (Isaac and Conger 2019). Luckily, the technology team came to the rescue with recording equipment of their own. The day also brought other unexpected problems: the private parking lot at Center City sold all the campus parking spaces to the Atlantic Coast Conference basketball tournament being held in Charlotte at the same time, without notifying the university. Late notifications had to be emailed to all registered guests to make them aware of the problem. Luckily, the Center City campus is located on Charlotte's Lynx light-rail line; guests could travel into downtown on the train. In the end, not all parking spots were taken, but the last-minute snafu caused several guests to cancel.

The project brought out passionate feelings from many throughout the library. As the library coordinated the project, it welcomed any faculty or staff member wishing to join. Faculty and staff from various sections of the library, including the board of advisors, participated in Beyond the Myths. Library staff and faculty volunteered to create exhibits, help register guests, coordinate the receptions, pass microphones during question-and-answer periods, welcome and escort guests, and help at the Sugar Creek Library, among other duties. One employee commented on the experience, "I was especially thrilled with the general public's attendance! So many I spoke with had never attended an Atkins event on campus (many had never even been on campus) or at Center City. All spoke very highly of the library and hoped to come back." Our best advice after implementing a multi-day, multi-event series is this: recognize the program's needs and ask for help; people are the greatest resource. 


\section{References}

Bynum, Victoria. 1987. "'War within a War': Women's Participation in the Revolt of the North Carolina Piedmont, 1863-1865." Frontiers: A Journal of Women Studies 9, no. 3: 43-49. https://doi.org/10.2307/3346260.

Cowell, Jane. 2020. "The Discussion We Need to Have: Social Justice." inCite 41: no. 1/2 (January/February): 30-31.

http:/ / read.alia.org.au/discussion-we-need-have-social-justice.

Drabinski, Emily. 2019. "What is Critical about Critical Librarianship?" Art

Libraries Journal 44 no. 2 (April): 49-57. https://doi.org/10.1017/alj.2019.3.

Duggan, Paul. 2018. "Jury Gives Fields Life in Prison." Washington Post, December 12, 2018. ProQuest Central.

Escott, Paul D., and Jeffrey J. Crow. 1986. "The Social Order and Violent Disorder: An Analysis of North Carolina in the Revolution and the Civil War." The Journal of Southern History 52, no. 3 (August): 373-402. https://doi.org/10.2307/2209568.

Isaac, Mike, and Kate Conger. 2019. "Facebook's Daylong Malfunction is a Reminder of the Internet's Fragility." New York Times, March 14, 2019. ProQuest Central.

Patel, Vimal. 2018. "Silent Sam Was Toppled. Yet He Still Looms Over Campus." Chronicle of Higher Education 65, no. 1 (August 29, 2018). Academic Search Complete.

\section{Author Details}

Beth Scarborough, Information Literacy and Instruction Librarian, University of North Carolina, Charlotte: Beth.Scarborough@uncc.edu

Susan Foster Pardue, Reserves Specialist, University of North Carolina, Charlotte: mspardue@uncc.edu 